\title{
Oznaczanie surfaktantów w próbkach środowiskowych pochodzących z terenów działalności górnictwa naftowego i gazownictwa
}

\begin{abstract}
Ze względu na powszechne stosowanie związków powierzchniowo czynnych, ich toksyczność oraz swobodne przemieszczanie w różnych elementach ekosystemu istotnym zagadnieniem staje się poznanie losu środowiskowego surfaktantów. Związki te obecne są również w produktach oraz odpadach wiertniczych. W niniejszym artykule przedstawiono wyniki walidacji spektrofotometrycznej metody oznaczania surfaktantów anionowych w próbkach odpadów o złożonej matrycy pochodzących z terenów działalności górnictwa naftowego i gazownictwa. Zaprezentowano również wyniki badań z zastosowaniem opracowanej metody dla próbek rzeczywistych, w tym próbek płynów do szczelinowania oraz próbek ciekłych i stałych odpadów wiertniczych.
\end{abstract}

Słowa kluczowe: oznaczanie surfaktantów, środki powierzchniowo czynne, odpady wiertnicze, ochrona środowiska.

\section{Determination of surfactants in environmental samples descending from areas of oil and gas industry activity}

\begin{abstract}
Due to the widespread use of surfactants, their toxicity and ability to move freely in different parts of the ecosystem, knowledge about environmental fate of surfactants becomes an important issue. These compounds are also present in drilling products as well as wastes. This article presents the results of validation of a spectrophotometric method for the determination of anionic surfactants in waste samples with complex matrix, deriving from areas of oil and gas industry activity. The article also shows the results of studies based on the developed method applied to real samples including fracturing fluids as well as liquid and solid drilling waste.
\end{abstract}

Key words: determination of surfactants, surface-active agents, drilling wastes, environmental protection.

\section{Wstęp}

Surfaktanty (ang. surface-active agents) są to substancje chemiczne, których cząsteczki składają się z dwóch części o przeciwstawnych właściwościach, tj. grupy hydrofilowej oraz hydrofobowej. Obecnie surfaktanty wykorzystywane są zarówno jako środki piorące, myjące, jak i w przemyśle spożywczym, włókienniczym, metalurgicznym, rafineryjnym, petrochemicznym, górniczym, elektronicznym, w syntezach związków oraz w analityce chemicznej. $Z$ uwagi na tak powszechne zastosowanie, ich toksyczność oraz swobodne przemieszczanie się w różnych elementach ekosystemu istotnym zagadnieniem staje się poznanie losu środowiskowego tych substancji. Niezbędne jest zatem opracowywanie proce- dur analitycznych, które pozwolą na jakościowe i ilościowe oznaczanie różnego typu surfaktantów w próbkach środowiskowych. Jedną z gałęzi gospodarki wykorzystujących surfaktanty jest górnictwo nafty i gazu. Ze względu na obecność związków powierzchniowo czynnych w produktach oraz odpadach wiertniczych, a także biorąc pod uwagę obowiązujące regulacje prawne określające limity zawartości tych substancji w próbkach środowiskowych, podjęto próbę oznaczenia ich zawartości w próbkach środowiskowych pochodzących z terenów działalności branży górnictwa naftowego i gazownictwa.

Tematyka związana z oznaczaniem jakościowym i ilościowym surfaktantów jest trudna, zwłaszcza gdy 
podejmowane są próby wyodrębnienia tych substancji z próbek o złożonej matrycy, takich jak próbki wód, ścieków i odpadów. Problemy napotykane podczas oznaczania tych substancji mogą wynikać z ich skomplikowanej budowy chemicznej oraz niskich stężeń oznaczanych w badanym materiale. Ze względu na właściwości fizykocheczęści polarnej surfaktantów) związki te można podzielić na dwie grupy: jonowe oraz niejonowe. Taki podział funkcjonuje również podczas doboru metod oznaczania tych substancji $[6,7,9]$.

Metody najczęściej wykorzystywane do oznaczania całkowitej zawartości surfaktantów w próbkach środowiskowych to: metody spektrofotometryczne [2, 6, 7, 9, 10, 13], miareczkowe (miareczkowanie potencjometryczne) $[5,7$, $9,12]$ oraz metody tensometryczne $[7,9,11,12]$. Z kolei do oznaczania poszczególnych związków wykorzystywane są zwykle techniki chromatograficzne, tj. chromatografia gazowa, cieczowa (z uwzględnieniem chromatografii jonowej) oraz elektroforeza kapilarna [7, 9]. Metody analityczne stosowane do oznaczenia sumarycznej zawartości surfaktantów z danej podgrupy charakteryzują się niewielką liczbą etapów przygotowania próbek (np. przeprowadzenie filtracji, reakcji prowadzących do powstania kompleksów barwnych oraz fotometryczne oznaczanie odpowiednich kompleksów miczne (tj. zdolność do dysocjacji w roztworach wodnych

analitów) [10]. Natomiast oznaczanie zawartości pojedynczych związków wymaga użycia właściwych technik ekstrakcyjnych przed końcowym etapem ich oznaczania (izolacja i/lub wzbogacanie analitu). Technikami ekstrakcyjnymi najczęściej wykorzystywanymi w celu oznaczania pojedynczych związków powierzchniowo czynnych są: ekstrakcja w układzie ciecz-ciecz (LLE) lub ciecz-ciało stałe, ekstrakcja za pomocą rozpuszczalnika w aparacie Soxhleta oraz ekstrakcja do fazy stałej (SPE) $[7,8]$.

Użytecznymi metodami służącymi do oznaczania surfaktantów w próbkach z branży górnictwa naftowego i gazownictwa są metody spektrofotometryczne. Zaleca je także polskie prawo do oceny zawartości tych związków w próbkach środowiskowych $[16,17,18]$. Metody te są znormalizowane, jednak odpowiednie normy opisują sposób oznaczania zawartości surfaktantów jedynie w próbkach wód i ścieków. Możliwość zastosowania tych norm do oznaczania surfaktantów w próbkach ciekłych odpadów powstających podczas zabiegów hydraulicznego szczelinowania oraz wyciągów wodnych odpadów wiertniczych pochodzących z wiercenia otworów pionowych i poziomych wymaga weryfikacji. Wyniki przeprowadzonych badań w zakresie oznaczania surfaktantów w próbkach odpadów wiertniczych metodą spektrofotometryczną przedstawiono w dalszej części niniejszego artykułu.

\section{Opis stosowanej techniki badawczej i jej walidacja}

Naturalne oraz syntetyczne anionowe substancje powierzchniowo czynne można oznaczać metodą wskaźnika ich sumarycznej zawartości jako substancje aktywne wobec błękitu metylenowego (MBAS, ang. methylene blue active substances). Zmierzoną $\mathrm{w}$ ten sposób wielkość określa się jako indeks MBAS [15]. Za pomocą tej metody oznacza się głównie organiczne siarczany(VI) i sulfoniany. Wartość MBAS może zostać zaniżona w obecności substancji kationowych, takich jak czwartorzędowe związki amoniowe oraz białka. Jeżeli w próbce zawarte są surfaktanty kationowe i anionowe, mogą one utworzyć trwałe związki kompleksowe, które nie są reaktywne względem błękitu metylenowego.

Zawyżone wartości indeksu MBAS mogą wynikać z obecności substancji tworzących z błękitem metylenowym związki rozpuszczalne w chloroformie. Wpływ takich substancji jest minimalizowany przez wydmuchiwanie surfaktantów z próbki do octanu etylu (wypienianie do rozpuszczalnika), co ma na celu oddzielenie ich od substancji nieaktywnych powierzchniowo. Wydmuchiwanie zaleca się również w celu wzbogacania próbki (w przypadku oznaczania małych zawartości surfaktantów) [15].
W ramach walidacji metody spektrofotometrycznego oznaczania surfaktantów anionowych wyznaczono i oceniono takie jej parametry jak liniowość, granice oznaczalności i wykrywalności, powtarzalność, poprawność, selektywność i odporność. Dla zwalidowanej metody określono również budżet niepewności.

Wzorcowanie przeprowadzono za pomocą dostępnego w handlu certyfikowanego materiału odniesienia (CRM) o stężeniu $1000 \mathrm{mg} / \mathrm{l} \pm 0,2 \%$ (dla $k=2, P=95 \%$ ) firmy Chem-Lab NV. Wyniki wzorcowania przedstawiono na rysunku 1 , natomiast parametry wykresu kalibracyjnego w tablicy 1 .

Tablica 1. Zestawienie parametrów regresyjnych wykresu krzywej wzorcowania dla spektrofotometrycznej metody oznaczania surfaktantów anionowych

\begin{tabular}{|l|c|c|}
\hline Współczynnik kierunkowy prostej & $b$ & 0,2672 \\
\hline Wyraz wolny & $a$ & $-0,0004$ \\
\hline $\begin{array}{l}\text { Odchylenie standardowe współczynnika } \\
\text { kierunkowego }\end{array}$ & $s_{b}$ & 0,0047 \\
\hline Odchylenie standardowe wyrazu wolnego & $s_{a}$ & 0,0080 \\
\hline Współczynnik korelacji & $r$ & 0,9997 \\
\hline Współczynnik determinacji & $R^{2}$ & 0,9994 \\
\hline
\end{tabular}




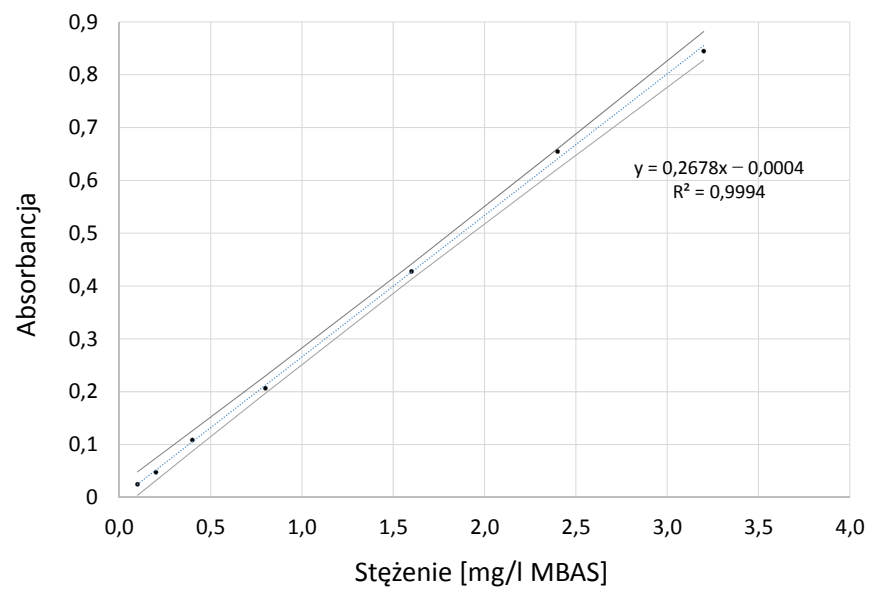

Rys. 1. Wykres zależności stężenia surfaktantów anionowych, wyrażonego jako indeks MBAS, od absorbancji wraz z wyznaczonymi przedziałami ufności

\section{Określenie granicy oznaczalności i wykrywalności spektrofotometrycznej metody oznaczania surfaktantów anionowych}

Norma [15] podaje, że granica wykrywalności w roztworach surfaktantów wzorcowych w wodzie destylowanej wynosi około 0,05 mg/l MBAS. Granica wykrywalności metody analitycznej została wyznaczona na podstawie pomiarów na niezależnie przygotowanych ślepych próbkach, w których oznaczono zawartość surfaktantów anionowych za pomoca metody spektrofotometrycznej. Dla otrzymanych w ten sposób wyników obliczono odchylenie standardowe $(S D)$. Granica wykrywalności $(L o D)$ i granica oznaczalności metody $(L o Q)$ zostały wyznaczone z następujących zależności (1) i (2):

$$
L o D=\frac{3,3 S D}{b} \quad \text { (1) } \quad L o Q=3 L o D
$$

gdzie: $b$-współczynnik kierunkowy prostej.

Wyniki obliczeń przedstawiono w tablicy 2.

Tablica 2. Zestawienie wyników obliczonych wartości granicy oznaczalności i wykrywalności dla spektrofotometrycznej metody oznaczania surfaktantów anionowych

\begin{tabular}{|c|c|c|c|}
\hline Parametr & $\begin{array}{c}n-\text { liczba } \\
\text { pomiarów }\end{array}$ & Wartość & Jednostka \\
\hline$L o D$ & 10 & 0,029 & $\mathrm{mg} / 1 \mathrm{MBAS}$ \\
\hline$L o Q$ & 10 & 0,087 & $\mathrm{mg} / \mathrm{l} \mathrm{MBAS}$ \\
\hline$S D$ & 10 & 0,003 & - \\
\hline
\end{tabular}

Obliczone wartości $L o D$ i $L o Q$ są zbliżone do wartości podanych w normie [15]
Weryfikację poprawności obliczonej granicy oznaczalności przeprowadzono na podstawie określenia powtarzalności (wyrażonej jako RSD (\%)) dla serii próbek zawierających analit na poziomie bliskim wyznaczonej granicy oznaczalności. Matrycę próbki stanowiła próbka ciekłego odpadu wiertniczego (płynu zwrotnego), którą wzbogacono przez dodanie odpowiednio rozcieńczonego certyfikowanego materiału referencyjnego, zawierającego $0,1 \mathrm{mg} / \mathrm{l} \mathrm{MBAS}$. Wyniki pomiarów i obliczeń zebrano w tablicy 3 .

Tablica 3. Zestawienie danych otrzymanych podczas weryfikacji poprawności wyznaczania granicy oznaczalności spektrofotometrycznej metody oznaczania surfaktantów anionowych

\begin{tabular}{|l|c|}
\hline \multicolumn{1}{|c|}{ Parametr } & Wartość \\
\hline Mediana [mg/l MBAS] & 0,100 \\
\hline Średnia arytmetyczna [mg/l MBAS] & 0,099 \\
\hline$S D$ & 0,012 \\
\hline$R S D[\%]$ & 11,7 \\
\hline Odzysk [\%] & 99,0 \\
\hline$n-$ liczba pomiarów & 8 \\
\hline
\end{tabular}

Granica oznaczalności metody została wyznaczona poprawnie ( $R S D$ poniżej $15 \%$ ). Obliczona wartość $L o Q$ jest bliska wartości podanej w normie [15].

\section{Powtarzalność i poprawność metody oznaczania surfaktantów anionowych}

Powtarzalność metody określono na podstawie badań próbek przygotowanych z certyfikowanego materiału odniesienia oraz próbek rzeczywistych wzbogaconych znaną ilością certyfikowanego materiału referencyjnego. Poprawność metody została wyznaczona poprzez zastosowanie testu $t$-Studenta porównującego istotność różnic między wartością zadaną a wartością średnią, a następnie przez porównanie obliczonej wartości parametru $\mathrm{z}$ wartością tablicową. Uzyskane na tym etapie wyniki walidacji metody spektrofotometrycznego oznaczania surfaktantów anionowych w próbkach odpadów wiertniczych zostały zawarte $\mathrm{w}$ tablicy 4.

Powtarzalność określona jako $R S D$ przyjmuje wartości z zakresu od 3,50\% do 12,0\%. Najmniejszą powtarzalność otrzymano dla serii próbek matrycowych o stężeniu z początku analizowanego zakresu. Obliczona wartość parametru t-Studenta nie przekracza wartości tablicowej. Porównywane wartości nie różnią się w sposób statystycznie istotny, można zatem uznać uzyskane wyniki za zgodne z wartością odniesienia, a metodę za dokładną. 
Tablica 4. Zestawienie parametrów wyznaczonych w ramach określania powtarzalności i poprawności metody spektrofotometrycznej oznaczania surfaktantów anionowych

\begin{tabular}{|l|c|c|c|}
\hline \multicolumn{1}{|c|}{ Stężenie założone [mg/l MBAS] } & 0,1 & 3,02 & 5,0 \\
\hline Mediana [mg/l MBAS] & 0,10 & 2,92 & 4,86 \\
\hline Średnia arytmetyczna [mg/l MBAS] & 0,099 & 2,94 & 4,90 \\
\hline$S D$ & 0,012 & 0,10 & 0,23 \\
\hline$R S D[\%]$ & 11,7 & 3,52 & 4,77 \\
\hline Odzysk [\%] & 99 & 97 & 98,0 \\
\hline Wartość parametru $t$-Studenta $(f=n-1=7, \alpha=0,05)$ & 0,19 & 2,07 & 1,16 \\
\hline Wartość krytyczna parametru $t$-Studenta $(f=n-1=7, \alpha=0,05)$ & 2,37 & 2,37 & 2,37 \\
\hline$n$ - liczba pomiarów & 8 & 8 & 8 \\
\hline
\end{tabular}

\section{Ocena selektywności oraz odporności metody spektrofotometrycznej oznaczania surfaktantów anionowych}

Selektywność metody oznaczania surfaktantów anionowych w próbkach odpadów wiertniczych została oceniona na podstawie wyników analiz próbek zawierających substancje przeszkadzające. Czynnikami przeszkadzającymi w oznaczeniu mogą być organiczne siarczany(VI), sulfoniany, karboksylany, fenole oraz cyjaniany, azotany(V), tiocyjaniany i siarczki $[1,15]$. Zawartość surfaktantów anionowych oznaczono w próbkach zawierających interferenty takie jak fenol oraz azotan(V) potasu, ponieważ takich substancji przeszkadzających można się spodziewać w próbkach środowiskowych pochodzących z terenów działalności branży górnictwa nafty i gazu. Uzyskane wyniki zestawiono w tablicy 5.

Jak już wspomniano wcześniej, do czynników przeszkadzających w oznaczeniu anionowych związków powierzchniowo czynnych można zaliczyć surfaktanty kationowe [1, 15]. Mogą one tworzyć trwałe związki kompleksowe, niereaktywne w stosunku do błękitu metylenowego. $Z$ tego względu przygotowano próbkę ścieku pochodzącego z przydomowej oczyszczalni ścieków, którą wzbogacono znaną ilością surfaktantów anionowych $(1,0 \mathrm{mg} / \mathrm{l})$, kationowych $(1,0 \mathrm{mg} / \mathrm{l})$ i niejonowych $(1,0 \mathrm{mg} / \mathrm{l})$. Następnie w próbce oznaczono zawartość anionowych związków powierzchniowo czynnych bez wydmuchiwania (wypieniania) oraz z wypienianiem do octanu etylu. Wzbogacona próbka została przesączona przed wykonaniem analiz. Uzyskane wyniki dla tak przygotowanych próbek przedstawiono $\mathrm{w}$ tablicy 6 .
Tablica 5. Zestawienie wyników określających wpływ potencjalnych substancji przeszkadzających na oznaczenie surfaktantów anionowych metodą spektrofotometryczną

\begin{tabular}{|c|c|c|c|c|}
\hline $\begin{array}{c}\text { Stężenie } \\
\text { surfaktantów } \\
\text { anionowych } \\
\text { w próbce } \\
\text { [mg/l MBAS] }\end{array}$ & $\begin{array}{c}\text { Dodany } \\
\text { interferent }\end{array}$ & $\begin{array}{c}\text { Zawartość } \\
\text { dodanego } \\
\text { interferenta } \\
{[\mathrm{mg}]}\end{array}$ & $\begin{array}{l}\text { Stężenie surfaktantów } \\
\text { anionowych w próbce } \\
\text { z interferentem } \\
\text { [mg/l MBAS }]\end{array}$ & $\begin{array}{c}\text { Odzysk } \\
{[\%]}\end{array}$ \\
\hline \multirow{10}{*}{2,25} & \multirow{6}{*}{ fenol } & 0,25 & 2,23 & 99,0 \\
\hline & & 0,50 & 2,21 & 98,0 \\
\hline & & 5,00 & 2,29 & 102,0 \\
\hline & & 20,0 & 2,26 & 101,0 \\
\hline & & 50,0 & 2,28 & 101,0 \\
\hline & & 200 & 2,25 & 100,0 \\
\hline & \multirow{4}{*}{$\mathrm{KNO}_{3}$} & 0,50 & 2,11 & 94,0 \\
\hline & & 20,0 & 2,09 & 93,0 \\
\hline & & 50,0 & 2,24 & 100,0 \\
\hline & & 200 & 2,23 & 99,0 \\
\hline
\end{tabular}

Tablica 6. Zestawienie wpływu substancji przeszkadzających na wynik oznaczenia surfaktantów anionowych

\begin{tabular}{|l|c|c|}
\hline \multicolumn{1}{|c|}{ Próbka / sposób postępowania } & $\begin{array}{c}\text { Stężenie } \\
{[\mathrm{mg} / \mathrm{l} \mathrm{MBAS}]}\end{array}$ & $\begin{array}{c}\text { Odzysk } \\
{[\%]}\end{array}$ \\
\hline Ściek z oczyszczalni bez dodatku CRM / sączenie & 0,12 & - \\
\hline $\begin{array}{l}\text { Ściek z oczyszczalni } \\
+1,0 \mathrm{mg} / \mathrm{l} \text { surfaktantów anionowych } \\
+1,0 \mathrm{mg} / \mathrm{l} \text { surfaktantów kationowych } \\
+1,0 \mathrm{mg} / \mathrm{l} \text { surfaktantów niejonowych / sączenie }\end{array}$ & 1,23 & 123 \\
\hline $\begin{array}{l}\text { Ściek z oczyszczalni } \\
+1,0 \mathrm{mg} / \mathrm{l} \text { surfaktantów anionowych } \\
+1,0 \mathrm{mg} / \mathrm{l} \text { surfaktantów kationowych } \\
+1,0 \mathrm{mg} / \mathrm{l} \text { surfaktantów niejonowych / sączenie, } \\
\text { wypienianie do octanu etylu }\end{array}$ & 0,94 & 94,1 \\
\hline
\end{tabular}


Analiza danych przedstawionych w tablicy 6 pozwala stwierdzić, że dodane substancje nie miały wpływu na wynik oznaczenia. Etap wypieniania do rozpuszczalnika również nie wpłynął w tym przypadku w znaczący sposób na uzyskany rezultat.

Odporność metody spektrofotometrycznej została określona na podstawie analizy otrzymanych wyników badań, dla których w procedurze oznaczania użyto innych niż podane w normie [15] objętości błękitu metylenowego. Zalecane przez normę objętości kwaśnego i obojętnego błękitu metylenowego stosowane do ekstrakcji to $5 \mathrm{ml}$. Odporność metody spektrofotometrycznego oznaczania surfaktantów anionowych w próbkach odpadów wiertniczych została sprawdzona poprzez przeprowadzenie oznaczenia z użyciem $1 \mathrm{ml}$ kwaśnego i $1 \mathrm{ml}$ obojętnego roztworu błękitu metylenowego oraz z zastosowaniem $10 \mathrm{ml}$ każdego ze wspomnianych odczynników. Dodanie mniejszych niż rekomendowane przez normę objętości kwaśnego i obojętnego roztworu błękitu mety- lenowego (1 ml) nieznacznie zaniżyło wyniki analizy (odzyski w granicach $87 \div 90 \%$ ). Dwukrotne zwiększenie objętości dodanych odczynników nie wpłynęło na wynik oznaczenia.

$\mathrm{W}$ ramach badań sprawdzono również, w jaki sposób na rezultat analizy wpływa czas, jaki upłynął od zakończenia ekstrakcji do wykonania pomiaru absorbancji. W normie [15] nie podano wytycznych dotyczących czasu prowadzenia pomiaru. Absorbancję roztworów kalibracyjnych oraz próbek mierzono w ciągu maksymalnie 5 minut od zakończenia ekstrakcji. W celu sprawdzenia odporności metody zmierzono absorbancję próbek ścieków w różnych odstępach czasu po wykonaniu ekstrakcji. Otrzymane dane wskazują na minimalny wzrost absorbancji w miarę upływu czasu. W związku z tym podczas oznaczania surfaktantów anionowych w próbkach odpadów wiertniczych metodą spektrofotometryczną zaleca się wykonywanie pomiaru absorbancji w czasie nieprzekraczającym 5 minut od zakończenia sączenia, po ekstrakcji próbki z kwaśnym błękitem metylenowym.

\section{Szacowanie niepewności spektrofotometrycznej metody oznaczania surfaktantów anionowych w próbkach odpadów wiertniczych}

Zidentyfikowane źródła niepewności spektrofotometrycznej metody oznaczania surfaktantów anionowych zostały przedstawione na diagramie (rysunek 2).

W dalszej części niniejszego podrozdziału opisano natomiast bardziej szczegółowo poszczególne parametry mające wpływ na niepewność złożoną metody.

\section{Niepewność etapu kalibracji $-u(k a l)$}

Standardową niepewność dla próbki o stężeniu $x_{p r}$ związaną z niepewnością przeprowadzenia kalibracji i zastosowania regresji liniowej można obliczyć zgodnie ze wzorami (3) i (4):

$$
u(k k)=\frac{S_{x y}}{b} \sqrt{\frac{1}{p}+\frac{1}{n}+\frac{\left(x_{p r}-x_{\dot{s} r}\right)^{2}}{Q_{x x}}}
$$

$$
Q_{x x}=\sum_{i=1}^{n}\left(x_{i}-x_{\dot{s} r}\right)^{2}
$$

gdzie:

$u(k k)$ - standardowa niepewność wyznaczenia zawartości surfaktantów anionowych na poziomie $x_{p r}$ związana z wykorzystaniem wykresu kalibracyjnego, $s_{x y}$ - resztkowe odchylenie standardowe,

$b$ - współczynnik kierunkowy krzywej kalibracyjnej,

$p$ - liczba pomiarów wykonywanych dla próbki,

$n$ - liczba punktów wzorcowania,

$x_{\dot{s} r}-$ średnie stężenie analitu w roztworach wzorcowych $[\mathrm{mg} / \mathrm{l}]$,

$x_{i}$ - stężenie analitu w poszczególnych roztworach wzorcowych $[\mathrm{mg} / \mathrm{l}]$,

$x_{p r}-$ stężenie analitu w badanej próbce [mg/l].

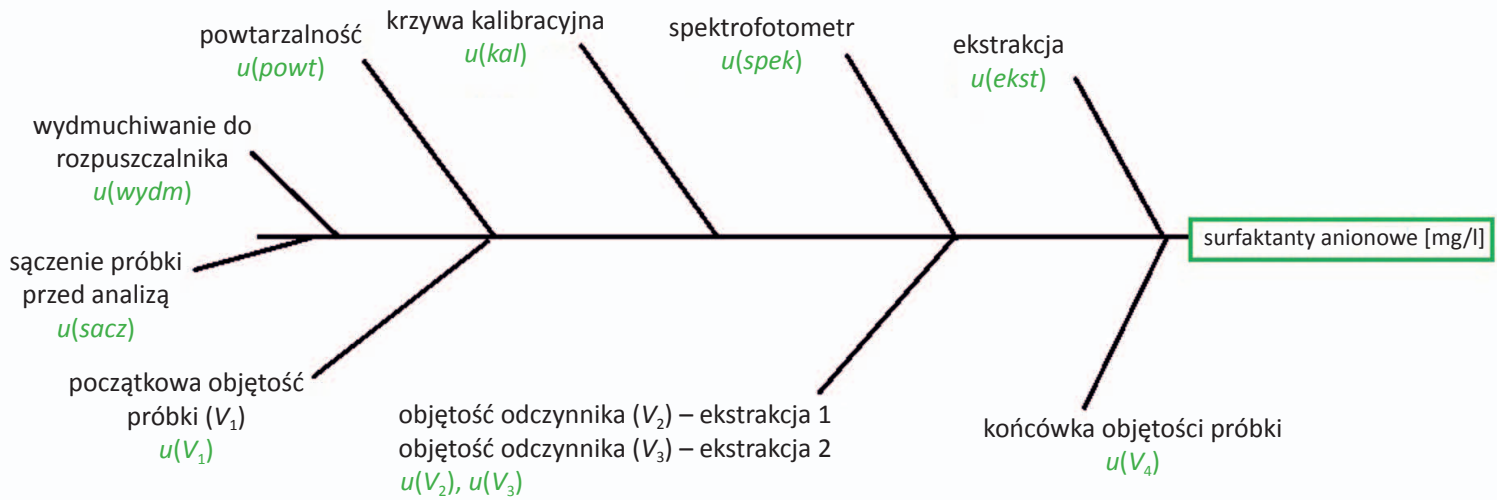

Rys. 2. Wpływ niepewności poszczególnych etapów i parametrów procesu analitycznego na wartość złożonej niepewności wyniku końcowego oznaczania surfaktantów anionowych w próbkach środowiskowych 
Niepewność związaną z kalibracją wyznaczono dla dwóch poziomów stężeń otrzymanych dla próbek odpadów wiertniczych o stężeniach 0,207 mg/1 MBAS oraz 2,30 mg/1 MBAS (tablica 7).

Tablica 7. Zestawienie parametrów wyznaczonych w ramach szacowania składowej niepewności związanej z etapem przygotowania krzywej kalibracyjnej

\begin{tabular}{|c|c|c|}
\cline { 2 - 3 } \multicolumn{1}{c|}{} & $X_{p r}=0,207 \mathrm{mg} / 1$ & $X_{p r}=2,30 \mathrm{mg} / 1$ \\
\hline$b$ & 0,2672 & 0,2672 \\
\hline$s_{x y}$ & 0,0126 & 0,0126 \\
\hline$p$ & 2 & 2 \\
\hline$n$ & 6 & 6 \\
\hline$x_{s r}$ & 1,41 & 1,41 \\
\hline$Q_{x x}$ & 7,27 & 7,27 \\
\hline $\boldsymbol{u ( k \boldsymbol { k } )}$ & $\mathbf{0 , 0 4 4}$ & $\mathbf{0 , 0 4 1}$ \\
\hline
\end{tabular}

Drugą składową niepewności wynikającą z etapu kalibracji jest niepewność związana z dwuetapowym przygotowaniem roztworów kalibracyjnych. W celu otrzymania roztworu do kalibracji o stężeniu 20 mg/l MBAS rozcieńczono roztwór certyfikowany opisany przez producenta jako $1000 \mathrm{mg} / 1 \pm 0,2 \%(k=2, P=95 \%)$. Rozcieńczenie przeprowadzono w dwóch etapach (1:10 oraz 1:5). Stosowano pipety o pojemności $10 \mathrm{ml}$ i $25 \mathrm{ml}$ oraz kolby miarowe $50 \mathrm{ml}$ i $250 \mathrm{ml}$. Niepewność związaną z dwuetapowym przygotowaniem roztworów kalibracyjnych obliczono, korzystając ze wzoru (5):

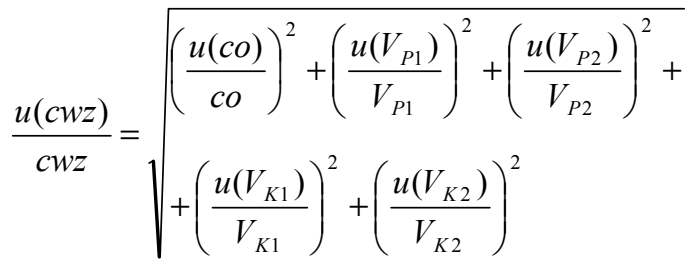

Składowe niepewności wynikające z etapu przygotowania roztworu do kalibracji $(u(c w z))$ zostały zebrane w tablicy 8. Założono, że wszystkie składowe charakteryzują się rozkładem prostokątnym.

Tablica 8. Zestawienie parametrów wyznaczonych w ramach szacowania składowej niepewności związanej z etapem przygotowania roztworu do kalibracji

\begin{tabular}{|c|c|c|c|}
\hline$V_{P 1}$ & $(25 \pm 0,03) \mathrm{ml}$ & $u(V p 1)$ & 0,017 \\
\hline$V_{P 2}$ & $(10 \pm 0,02) \mathrm{ml}$ & $u(V p 2)$ & 0,012 \\
\hline$V_{K 1}$ & $(50 \pm 0,06) \mathrm{ml}$ & $u(V k 1)$ & 0,035 \\
\hline$V_{K 2}$ & $(250 \pm 0,15) \mathrm{ml}$ & $u(V k 2)$ & 0,087 \\
\hline$c o$ & $1000 \mathrm{mg} / 1 \pm 0,2 \%$ & $u(c o)$ & 1,0 \\
\hline $\boldsymbol{c w z}$ & $\mathbf{2 0} \mathbf{~ m g / l}$ & $\boldsymbol{u}(\boldsymbol{c w z})$ & $\mathbf{0 , 0 3 7}$ \\
\hline
\end{tabular}

Składowa niepewności pochodząca z etapu kalibracji $u(k a l)$ wynosi zatem, zgodnie ze wzorem (6):

$$
\begin{aligned}
& u(k a l)=\sqrt{u(k k)^{2}+u(c w z)^{2}} \\
& u(k a l)=5,7 \%
\end{aligned}
$$

Niepewność związana z rozrzutem wyników pomiarów $-u($ powt $)$

Walidacja metody wykazała, że powtarzalność oznaczania surfaktantów anionowych, wyrażona jako względne odchylenie standardowe $R S D$, wynosi $11,7 \%$ dla stężenia $0,1 \mathrm{mg} / \mathrm{l}$; $3,52 \%$ dla $3,02 \mathrm{mg} / 1$ oraz 4,77\% w przypadku stężenia równego 5,0 mg/l (tablica 4). Zatem niepewność związana z powtarzalnością została oszacowana dla trzech poziomów stężeń z zakresu pomiarowego metody i wynosi odpowiednio:

- $u($ powt 1$)=11,7 \%$ (dla stężeń z początku zakresu stosowania metody);

- $u($ powt 2$)=3,52 \%$ (dla stężeń ze środka zakresu stosowania metody);

- $u($ powt 3$)=4,77 \%$ (dla stężeń z końca zakresu stosowania metody).

\section{Wydajność ekstrakcji}

W trakcie oceny niepewności związanej z efektywnością ekstrakcji przeanalizowano wyniki odzysku uzyskane dla trzech poziomów stężeń (tablica 9).

Tablica 9. Zestawienie wyników otrzymanych podczas szacowania składowej niepewności wynikającej z etapu ekstrakcji

\begin{tabular}{|l|c|c|c|}
\hline $\begin{array}{c}\text { Stężenie założone } \\
\text { [mg/1 MBAS] }\end{array}$ & 0,1 & 3,02 & 5,0 \\
\hline $\begin{array}{l}\text { Średnia arytmetyczna } \\
{[\mathrm{mg} / \mathrm{l} \mathrm{MBAS]}}\end{array}$ & 0,099 & 2,944 & 4,904 \\
\hline$S D$ & 0,0116 & 0,104 & 0,234 \\
\hline$R S D[\%]$ & 11,7 & 3,52 & 4,77 \\
\hline Odzysk [\%] & 99 & 97 & 98 \\
\hline
\end{tabular}

Niepewność wynikająca z wydajności ekstrakcji oszacowana została dla stężenia, dla którego otrzymano najniższą wartość odzysku (3,02 mg/l), w następujący sposób:

$$
u(e k s t)=\frac{3 \%}{\sqrt{3}}=1,73 \%
$$

Niepewność wynikająca z konieczności wydmuchiwania surfaktantów (wypieniania do rozpuszczalnika) $-u(w y d m)$

Składową niepewności związaną z etapem wypieniania surfaktantów anionowych do rozpuszczalnika oszacowano na podstawie porównania wyników próbek matrycowych, 
Tablica 10. Zestawienie wyników analiz dla próbki odpadu wiertniczego oraz wpływ etapu wypieniania do rozpuszczalnika na wynik oznaczania surfaktantów anionowych metodą spektrofotometryczną

\begin{tabular}{|c|c|c|}
\hline Próbka / sposób postępowania & $\begin{array}{l}\text { Stężenie } \\
\text { mg/l MBAS }\end{array}$ & Odzysk [\%] \\
\hline $\begin{array}{l}\text { Próbka płynu zwrotnego bez dodatku } \\
\text { CRM / sączenie, bez wydmuchiwania }\end{array}$ & 0,224 & - \\
\hline $\begin{array}{l}\text { Płyn zwrotny z manifoldu }+3,00 \mathrm{mg} / \mathrm{l} \\
\text { MBAS / sączenie, bez wydmuchiwania }\end{array}$ & 2,480 & 82,5 \\
\hline \multirow{2}{*}{$\begin{array}{l}\text { Płyn zwrotny z manifoldu }+3,00 \mathrm{mg} / 1 \\
\text { MBAS / sączenie, z wydmuchiwaniem }\end{array}$} & \multirow{2}{*}{2,140} & $\begin{array}{c}86,3 \\
\text { (do obliczeń jako } 100 \% \text { przyjęto stężenie } 2,30 \mathrm{mg} / \mathrm{l} \text {, czyli } \\
\text { stężenie surfaktantów otrzymane bez wydmuchiwania) }\end{array}$ \\
\hline & & $\begin{array}{c}71,3 \\
\text { (do obliczeń jako 100\% przyjęto stężenie } 3,00 \mathrm{mg} / \mathrm{l} \text {, czyli } \\
\text { stężenie dodanego CRM) }\end{array}$ \\
\hline
\end{tabular}

wzbogaconych o dodatek 3,00 mg/1 MBAS, otrzymanych bez wydmuchiwania oraz poddanych wypienianiu do octanu etylu. Próbka przed wydmuchiwaniem, a po dodaniu certyfikowanego roztworu odniesienia (MBAS) została przesączona przez średni sączek jakościowy. Każdą próbkę zbadano dwukrotnie, a średnie wyniki oznaczeń oraz otrzymane odzyski zebrano w tablicy 10 .

Odzysk otrzymany dla próbki poddanej wydmuchiwaniu $(86,3 \%)$ znajduje się na podobnym poziomie co odzysk dla próbki niepoddawanej temu etapowi procedury analitycznej $(82,5 \%)$. Stąd niepewność:

$$
u(w y d m)=\frac{13,7 \%}{\sqrt{3}}=7,9 \%
$$

Natomiast składowa niepewności związana z etapem sączenia próbki przed analizą $-u(s a c z)$ ma wartość:

$$
u(\operatorname{sacz})=\frac{17,5 \%}{\sqrt{3}}=10,0 \%
$$

\section{Niepewność pochodząca z wzorcowania}

spektrofotometru $-u$ (spek)

Błąd wskazań spektrofotometru wyznaczony podczas wzorcowania dla długości fali 536,5 nm wynosi 0,1 nm (wartość certyfikowana to $536,6 \mathrm{~nm}$, natomiast zmierzona była równa 536,5 nm). Niepewność pochodząca z wzorcowania $u($ spek) została oszacowana w następujący sposób:

$$
\begin{aligned}
& u(\text { spek })=\frac{0,1 \mathrm{~nm}}{\sqrt{3}}=0,058 \mathrm{~nm} \\
& u(\text { spek })=0,011 \%
\end{aligned}
$$

Niepewność związana z odmierzaniem początkowej $u\left(V_{1}\right)$ i końcowej $u\left(V_{4}\right)$ objętości próbki

Próbka do analizy była przygotowywana w kolbie miarowej klasy A o pojemności $100 \mathrm{ml} \pm 0,1 \mathrm{ml}$. Składowa niepewności związana z początkową objętością próbki wynosi:

$$
\begin{aligned}
& u\left(V_{1}\right)=\frac{0,1 \mathrm{ml}}{\sqrt{3}}=0,058 \mathrm{ml} \\
& u\left(V_{1}\right)=0,058 \%
\end{aligned}
$$

W końcowym etapie analizy próbka po ekstrakcji zbierana była w kolbie miarowej klasy A o pojemności $50 \mathrm{ml} \pm 0,06 \mathrm{ml}$. W związku z tym składowa niepewności związana z objętością roztworu końcowego wyekstrahowanej próbki wynosi:

$$
\begin{aligned}
& u\left(V_{4}\right)=\frac{0,06 \mathrm{ml}}{\sqrt{3}}=0,035 \mathrm{ml} \\
& u\left(V_{4}\right)=0,070 \%
\end{aligned}
$$

Niepewność związana z odmierzaniem odczynników $-u\left(V_{2}\right), u\left(V_{3}\right)$

Kwaśny i obojętny roztwór błękitu metylenowego dodawano przy użyciu pipet wielomiarowych klasy A o objętości $5 \mathrm{ml} \pm 0,03 \mathrm{ml}$. Niepewność wynikająca z objętości odczynników przedstawia się następująco:

$$
\begin{aligned}
& u\left(V_{2}\right)=u\left(V_{3}\right)=\frac{0,03 \mathrm{ml}}{\sqrt{3}}=0,017 \mathrm{ml} \\
& u\left(V_{2}\right)=u\left(V_{3}\right)=0,34 \%
\end{aligned}
$$

W celu obliczenia złożonej niepewności standardowej $u(z)$ spektrofotometrycznej metody oznaczania surfaktantów anionowych w próbkach odpadów wiertniczych uwzględniono niepewności standardowe każdego składnika w następujący sposób:

$$
u(z)=\sqrt{\begin{array}{l}
(u(k a l))^{2}+(u(\text { powt }))^{2}+(u(\text { ekst }))^{2}+ \\
+(u(\text { wydm }))^{2}+(u(\text { sacz }))^{2}+(u(\text { spek }))^{2}+ \\
+\left(u\left(V_{1}\right)\right)^{2}+\left(u\left(V_{2}\right)\right)^{2}+\left(u\left(V_{3}\right)\right)^{2}+\left(u\left(V_{4}\right)\right)^{2}
\end{array}}
$$

Niepewność rozszerzoną $U(c)$ otrzymano przez pomnożenie złożonej niepewności standardowej przez współczynnik rozszerzenia 2 , uzyskując: 
- $u(z)=18,3 \%, U(c)=36,6 \%$ dla stężeń z początku zakresu stosowanej metody;

- $u(z)=14,5 \%, U(c)=29,0 \%$ dla stężeń ze środka zakresu stosowanej metody;

- $u(z)=14,9 \%, U(c)=29,7 \%$ dla stężeń z końca zakresu stosowanej metody.

Powyższe wartości niepewności rozszerzonej zostały oszacowane dla metody oznaczania surfaktantów anionowych uwzględniającej etap sączenia i wypieniania do rozpuszczalnika.

\section{Wyniki oznaczania surfaktantów anionowych w próbkach środowiskowych pochodzących z działalności górnictwa naftowego i gazownictwa}

Zwalidowana spektrofotometryczna metoda oznaczania surfaktantów anionowych w próbkach środowiskowych została
Tablica 11. Zestawienie wyznaczonych niepewności rozszerzonych oszacowanych dla metody oznaczania surfaktantów anionowych w przypadku niewymagającym etapu sączenia i/lub wypieniania do rozpuszczalnika

\begin{tabular}{|c|c|c|c|}
\hline $\begin{array}{c}\text { Stężenie } \\
\text { surfaktantów } \\
\text { anionowych }\end{array}$ & $\begin{array}{c}U(c) \\
k=2 \\
\text { (bez sączenia) }\end{array}$ & $\begin{array}{c}U(c) \\
k=2 \\
\text { (bez wypieniania } \\
\text { do rozpuszczalnika) }\end{array}$ & $\begin{array}{c}U(c) \\
k=2\end{array}$ \\
\hline $0,1 \mathrm{mg} / 1$ & $30,7 \%$ & $33,0 \%$ & $26,3 \%$ \\
\hline $3,0 \mathrm{mg} / 1$ & $21,0 \%$ & $24,3 \%$ & $13,9 \%$ \\
\hline $5,0 \mathrm{mg} / 1$ & $22,0 \%$ & $25,2 \%$ & $15,3 \%$ \\
\hline
\end{tabular}

Niepewności rozszerzone oszacowane dla metody niewymagającej etapu sączenia i/lub wydmuchiwania zostały natomiast zebrane w tablicy 11 .

Tablica 12. Zestawienie wyników oznaczania stężenia surfaktantów anionowych w próbkach środowiskowych oraz próbkach pochodzących $\mathrm{z}$ terenów działalności górnictwa naftowego i gazownictwa

\begin{tabular}{|c|c|c|c|}
\hline Lp. & Opis próbki & Stężenie & Jednostka \\
\hline Próbka nr 1 & płyn szczelinujący & 2,940 & \multirow{20}{*}{$\mathrm{mg} / \mathrm{l} \mathrm{MBAS}$} \\
\hline Próbka nr 2 & płyn szczelinujący & 2,160 & \\
\hline Próbka nr 3 & płyn szczelinujący & 0,632 & \\
\hline Próbka nr 4 & płyn szczelinujący & 1,700 & \\
\hline Próbka nr 5 & płyn szczelinujący & 0,704 & \\
\hline Próbka nr 6 & płyn zwrotny (otwarty zbiornik) & 0,256 & \\
\hline Próbka nr 7 & płyn zwrotny (separator) & 0,207 & \\
\hline Próbka nr 8 & płyn zwrotny (separator) & 0,211 & \\
\hline Próbka nr 9 & płyn zwrotny (separator) & 0,209 & \\
\hline Próbka nr 10 & płyn zwrotny & 0,129 & \\
\hline Próbka nr 11 & płyn zwrotny & 0,314 & \\
\hline Próbka nr 12 & płyn zwrotny & 0,393 & \\
\hline Próbka nr 13 & płyn zwrotny & 0,222 & \\
\hline Próbka nr 14 & płyn zwrotny & 0,185 & \\
\hline Próbka nr 15 & płyn zwrotny & 0,179 & \\
\hline Próbka nr 16 & płyn zwrotny & 0,147 & \\
\hline Próbka nr 17 & płyn zwrotny & 0,224 & \\
\hline Próbka nr 18 & płyn zwrotny & 0,162 & \\
\hline Próbka nr 19 & płyn zwrotny & 0,325 & \\
\hline Próbka nr 20 & płyn zwrotny & 0,202 & \\
\hline Próbka nr $21^{*}$ & odpad wiertniczy o kodzie 010505 po wirówce pionowej 3785 m & 1,550 & \multirow{3}{*}{$\mathrm{mg} / \mathrm{kg} \mathrm{MBAS}$} \\
\hline Próbka nr $22^{*}$ & odpad wiertniczy o kodzie 010505 przed wirowaniem na wirówce pionowej $3785 \mathrm{~m}$ & 0,906 & \\
\hline Próbka nr $23^{*}$ & odpad wiertniczy urobek (vert. G + wirówki) $4330 \mathrm{~m}$ & 1,090 & \\
\hline
\end{tabular}

Odpad w postaci stałej - analizowano wyciąg wodny odpadu (1:10) 
górnictwa naftowego i gazownictwa. Uzyskane dla badanych próbek odpadów rezultaty przedstawiono w tablicy 12, przy czym tablica ta zawiera średnią arytmetyczną z dwóch wyników.
W przypadku oznaczania surfaktantów anionowych w próbkach stałych sporządzono wyciąg wodny 1:10, który został poddany analizie po 24 godzinach od momentu przygotowania.

\section{Dyskusja wyników}

Najczęściej stosowanymi metodami oznaczania całkowitej zawartości związków powierzchniowo czynnych w próbkach środowiskowych są metody spektrofotometryczne, metody miareczkowe (miareczkowanie potencjometryczne) oraz metody tensometryczne. Natomiast do oznaczania poszczególnych związków wykorzystywane są zwykle techniki chromatograficzne, tj. chromatografia gazowa, chromatografia cieczowa (z uwzględnieniem chromatografii jonowej) oraz elektroforeza kapilarna. Dobranie odpowiedniej metody nie jest łatwe i zależy od wielu czynników. Wybór metody spektrofotometrycznej do oznaczania surfaktantów anionowych w próbkach środowiskowych o skomplikowanej matrycy wynikał głównie z rekomendowania tej metody przez rozporządzenie [16] jako metodyki referencyjnej przeznaczonej do badania próbek ścieków.

Spektrofotometryczna metoda oznaczania surfaktantów anionowych została zwalidowana i potwierdzono poprawność jej stosowania. Walidacja metody objęła analizę czynników wpływających na wynik pomiaru (źródła niepewności), określenie zakresu liniowości krzywej wzorcowej, wyznaczenie granicy oznaczalności metody oraz sprawdzenie osiąganej powtarzalności, selektywności, odporności i popraw- ności. Ustalono, że krzywa wzorcowa jest liniowa w przedziale stężeń od 0,1 mg/l MBAS do 5,0 mg/1 MBAS. Wyznaczono wartość granicy oznaczalności, która dla spektrofotometru UNICAM UV 300 wynosi 0,087 mg/1 MBAS. Oszacowana niepewność rozszerzona wyniku oznaczania stężenia surfaktantów anionowych na poziomie 3,0 mg/l MBAS jest równa 29\% (dla poziomu ufności 95\% i $k=2$ ). Podstawowymi źródłami niepewności podczas analizy próbek z zastosowaniem przyjętej procedury analitycznej są straty analitu powstające na etapach przygotowania próbki do analizy (rozcieńczanie próbki, sączenie, wypienianie do rozpuszczalnika) oraz podczas ekstrakcji z użyciem roztworów błękitu metylenowego.

Efekt interferencyjny, wywołany obecnością w analizowanej próbce składnika lub składników towarzyszących oznaczanym związkom, nie został stwierdzony.

Metoda spektrofotometryczna może być z powodzeniem stosowana w przypadku określania zawartości surfaktantów anionowych w próbkach środowiskowych pochodzących z branży górnictwa nafty i gazu, które często są niestabilne i charakteryzują się stosunkowo skomplikowaną matrycą oraz składem przeważnie nieznanym analitykowi.

Prosimy cytować jako: Nafta-Gaz 2017, nr 5, s. 340-349, DOI: 10.18668/NG.2017.05.06

Artykuł nadesłano do Redakcji 8.12.2016 r. Zatwierdzono do druku 7.03.2017 r.

Artykuł powstał na podstawie pracy statutowej pt. Analiza możliwości oznaczania surfaktantów w próbkach środowiskowych praca INiG - PIB na zlecenie MNiSW; nr zlecenia: 0103/GE/16, nr archiwalny: DK-4100-103/16.

\section{Literatura}

[1] Draghici C., Coman D., Sica M., Dima C.: Method validation and uncertainty estimation for anionic surfactants determination from municipal wastewaters. Revue Roumaine de Chimie 2013, vol. 58, no. 7-8, s. 711-716.

[2] Khaled E., Mohamed G.G., Awad T.: Disposal screen-printed carbon paste electrodes for the potentiometric titration of surfactants. Sensors and Actuators B: Chemical 2008, vol. 135, no. 1 , s. $74-80$.

[3] Krasińska A., Król A., Dobrzańska M.: Wstępne przygotowanie próbek o skomplikowanej matrycy do badań metoda chromatografii jonowej. Nafta-Gaz 2013, nr 4, s. 329-340.

[4] Krasińska A., Król A., Kukulska-Zając E.: Ocena szkodliwości odpadów wiertniczych na podstawie badań wyciagów wodnych. Nafta-Gaz 2009, nr 9, s. 697-705.

[5] Lizondo-Sabater J., Martínez-Máñez R., Sancenón F., Seguí M.J., Soto J.: Ion-selective electrodes for anionic surfactants using a cyclam derivative as ionophore. Talanta 2008, vol. 75 , no. 1 , s. 317-325.

[6] Olkowska E., Polkowska Ż.: Wykorzystanie techniki chroma- tografii jonowej $w$ analityce surfaktantów $w$ próbkach wód powierzchniowych. [W:] Michalski R. (red.): Chromatografia jonowa. Instytut Podstaw Inżynierii Środowiska PAN, Zabrze 2012.

[7] Olkowska E., Polkowska Ż., Namieśnik J.: Analytical procedures for the determination of surfactants in environmental samples. Talanta 2012, vol. 88, s. 1-13.

[8] Olkowska E., Polkowska Ż., Namieśnik J.: Występowanie surfaktantów w próbkach środowiskowych. Wiadomości Chemiczne 2010, z. 64, s. 9-10.

[9] Polkowska Ż., Olkowska E.: Oznaczanie wybranych zwiazków z grupy jonowych surfaktantów w próbkach środowiskowych z wykorzystaniem techniki chromatografi jonowej. [W:] Michalski R. (red.): Postępy chromatografii jonowej. Instytut Podstaw Inżynierii Środowiska PAN, Zabrze 2014.

[10] Ŕodenas-Torralba E., Reis B.F., Morales-Rubio A., de la Guardia M.: An environmentally friendly multicommutated alternative to the reference method for anionic surfactants determination in water. Talanta 2005, vol. 66, no. 3, s. 591-599. 
[11] Szymański A., Wyrwas B., Łukaszewski Z.: Application of an indirect tensammetric method for the determination of non-ionic surfactants in surface water. Analytica Chimica Acta 1995, vol. 305, no. 1-3, s. 256-264.

[12] Traverso-Soto J.M., González-Mazo E., Lara-Martín P.A.: Analysis of Surfactants in Environmental Samples by Chromatographic Techniques. [W:] de Azevedo Calderon L. (ed.): Chromatography - The Most Versatile Method of Chemical Analysis; www.intechopen.com/books/chromatography-themost-versatile-method-of-chemical-analysis (dostęp: wrzesień 2016).

[13] Zhu Z., Hao Z., Li Z., Chen J.: Direct spectrophotometric determination of alkylphenol polyethoxylate nonionic surfactants in wastewater. Water Research 2003, vol. 37, no. 18, s. 4506-4512.

[14] Zieliński R.: Surfaktanty towaroznawcze i ekologiczne aspekty ich stosowania. Wydawnictwo Akademii Ekonomicznej w Poznaniu, Poznań 2000.

\section{Akty prawne i normatywne}

[15] PN-EN 903:2002 Jakość wody - Oznaczanie surfaktantów anionowych przez pomiar indeksu błękitu metylenowego MBAS.

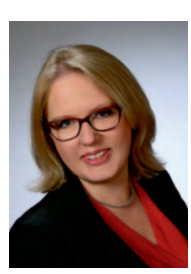

Mgr Anna KRÓL

Starszy specjalista badawczo-techniczny w Zakładzie Ochrony Środowiska.

Instytut Nafty i Gazu - Państwowy Instytut Badawczy

ul. Lubicz 25 A

31-503 Kraków

E-mail:anna.krol@inig.pl
[16] Rozporządzenie Ministra Środowiska z dnia 18 listopada 2014 r. w sprawie warunków, jakie należy spełnić przy wprowadzaniu ścieków do wód lub do ziemi, oraz w sprawie substancji szczególnie szkodliwych dla środowiska wodnego (Dz.U. z 2014 r., poz. 1800).

[17] Rozporządzenie Ministra Środowiska z dnia 19 lipca 2016 r. w sprawie form i sposobu prowadzenia monitoringu jednolitych części wód powierzchniowych i podziemnych (Dz.U. z 2016 r., poz. 1178).

[18] Rozporządzenie Ministra Środowiska z dnia 27 listopada 2002 r. w sprawie wymagań, jakim powinny odpowiadać wody powierzchniowe wykorzystywane do zaopatrzenia ludności w wodę przeznaczoną do spożycia (Dz.U. z $2002 \mathrm{r}$. Nr 204, poz. 1728).

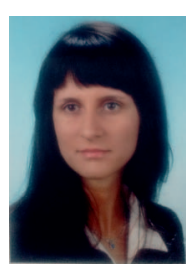

Mgr Monika Gajec

Starszy specjalista inżynieryjno-techniczny

w Zakładzie Ochrony Środowiska

Instytut Nafty i Gazu - Państwowy Instytut Badawczy ul. Lubicz 25 A

31-503 Kraków

E-mail:monika.gajec@inig.pl

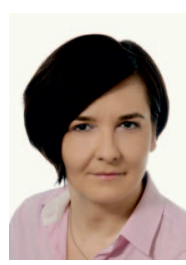

Dr Ewa KUKULSKA-ZAJĄC

Adiunkt; kierownik Zakładu Ochrony Środowiska. Instytut Nafty i Gazu - Państwowy Instytut Badawczy ul. Lubicz $25 \mathrm{~A}$

31-503 Kraków

E-mail: kukulska@inig.pl

\section{OFERTA}

\section{ZAKŁAD OCHRONY ŚRODOWISKA}

Zakres działania:

- $\quad$ analiza zagrożeń środowiska, związanych z działalnością przemysłu naftowego i gazowniczego,

- opracowanie i weryfikacja technologii środowiskowych w przemyśle nafty i gazu,

- $\quad$ monitoring i badania laboratoryjne jakości środowiska (powietrza, wód i gleby) na terenach poszukiwania i eksploatacji złóż węglowodorów i innych terenach przemysłowych,

- badania laboratoryjne ścieków (w tym wód złożowych i cieczy technologicznych) i odpadów (w tym odpadów wiertniczych, odpadów po zabiegu hydraulicznego szczelinowania) oraz ocena ich potencjalnej szkodliwości dla środowiska,

- $\quad$ klasyfikacja odpadów wydobywczych wraz ze sporządzaniem podstawowej charakterystyki odpadu,

- $\quad$ analiza zawartości rtęci w próbkach środowiskowych (stałych i ciekłych), mieszaninach gazowych i materiałach przemysłowych,

- $\quad$ inwentaryzacja emisji metanu z sektora poszukiwania, wydobycia, magazynowania oraz przesyłu i dystrybucji gazu,

- $\quad$ ocena wielkości emisji gazów cieplarnianych,

- $\quad$ ocena jakości paliw węglowodorowych: gazu ziemnego, koksowniczego, gazów wytwarzanych w przemyśle, biogazu,

- $\quad$ kompleksowa analiza biogazu, w tym analiza związków krzemu, chloru i fluoru,

- $\quad$ monitoring jakości gazu ziemnego w systemie gazowniczym,

- badania podkładów kolejowych odpadowych, wykorzystywane do ich klasyfikacji pod względem bezpieczeństwa dla środowiska,

- $\quad$ sporządzanie oraz aktualizacja kart charakterystyki substancji i mieszanin niebezpiecznych, zgodnie z obowiązującym prawodawstwem,

- $\quad$ pobór próbek wód, ścieków, gleb, odpadów oraz gazu ziemnego, biogazu i innego typu mieszanin gazowych.

Kierownik: dr Ewa Kukulska-Zając

Adres: ul. Bagrowa 1, 30-733 Kraków

Telefon: 12617743

Faks: 126531665

E-mail: ewa.kukulska@inig.p 